\title{
Identification of Environmental Factors Related to Claviceps purpurea Ascospore Production in Perennial Ryegrass Seed Fields and Development of Predictive Models
}

Jeremiah K. S. Dung, Department of Botany and Plant Pathology, Central Oregon Agricultural Research Center, Oregon State University, Madras, OR; Stephen C. Alderman, USDA-ARS National Forage Seed Production Research Center, Corvallis, OR; Navneet Kaur, Department of Botany and Plant Pathology, Hermiston Agricultural Research and Extension Center, Oregon State University, Hermiston, OR; Darrin L. Walenta, Department of Crop and Soil Science, Union County Extension Center, La Grande, OR; Kenneth E. Frost and Philip B. Hamm, Department of Botany and Plant Pathology, Hermiston Agricultural Research and Extension Center, Oregon State University, Hermiston, OR

\begin{abstract}
Claviceps purpurea, the causal agent of ergot of perennial ryegrass seed crops, overwinters as sclerotia in the soil and releases airborne ascospores in the spring that infect flower ovaries and replace seed with sclerotia. Burkard spore traps were used to quantify the dispersal phenology and concentration of ascospores in perennial ryegrass seed fields in the Columbia Basin of Oregon. Weather factors were measured concurrently with spore trapping. Nonparametric regression, box-and-whisker plots, and univariate analysis were used to visualize and identify trends between ascospore concentrations and weather variables. Most ascospores (75.4\%) were trapped when minimum soil temperatures were between 16.2 and $20.4^{\circ} \mathrm{C}$. Over $67 \%$ of the total ascospores trapped were observed when minimum air temperatures were between 6.8 and $12.4^{\circ} \mathrm{C}$ and $64 \%$ of ascospores were trapped

when daily mean dew point was between 3.7 and $8.2^{\circ} \mathrm{C}$. Environmental favorability index (EFI) models were developed and validated based on their ability to predict ascospore occurrence. The EFI models were able to predict ascospore occurrence with an accuracy of 71.7 to $87.5 \%$ depending on the year. The models were up to $79.8 \%$ accurate when validated using three years of historical spore trap data not used in the EFI model development. Ninety-four percent of ascospores were trapped when cumulative air degree days, using lower and upper thresholds of 10 and $25^{\circ} \mathrm{C}$, respectively, were between 230 and 403 . These results suggest that weather parameters can be used to model C. purpurea ascospore occurrence and potentially improve the timing and efficacy of fungicide applications by identifying when plant protection is most needed.
\end{abstract}

Oregon is a major producer of perennial ryegrass (Lolium perenne L.) seed, where in 2013 over 71,000 metric tons of seed were harvested from 42,700 ha with a production value of over \$111 million US (Anonymous 2014). Perennial ryegrass seed is used for permanent pastures for both hay and forage, home and commercial lawns, and recreational and sporting turf. Most production of this crop occurs in the Willamette Valley of western Oregon. Since 1997, production acreage of ryegrass seed in the Columbia Basin of eastern Oregon has increased from approximately 728 ha to over 3,800 ha in 2012 (USDA-NASS 2012). Besides its economic value, perennial ryegrass has become an important perennial rotation crop in the cropping systems of eastern Oregon.

Ergot, caused by the fungal pathogen Claviceps purpurea (Fr.) Tul., is an important seed replacement disease of grasses and a long-standing problem in Oregon perennial ryegrass and Kentucky bluegrass seed production systems (Alderman et al. 1993; Alderman et al. 1998; Butler et al. 2001; Dung et al. 2016a; Walenta et al. 2008). The fungus has a wide host range, including important grains grown for human and livestock consumption as well as forage and weedy grasses (Alderman et al. 2004). The pathogen infects the flowers of grasses before fertilization, colonizing the ovaries and resulting in the production of sclerotia instead of viable seed (Alderman 2006; Luttrell 1980; Tudzynski and Scheffer 2004). Sclerotia are left behind in fields after harvest (Alderman et al. 1993; Dung et al. 2016; Markhasseva 1936) and serve as the overwintering structures of the pathogen. Sclerotia germinate to produce capitula, which release primary inoculum in the form of airborne ascospores the following season. After primary infection of flowers by ascospores,

Corresponding author: J. K. S. Dung;

E-mail: jeremiah.dung@oregonstate.edu

Accepted for publication 17 January 2017.

(C) 2017 The American Phytopathological Society conidia are produced in large numbers and mix with plant sap exuded from infected ovaries to form a substance referred to as honeydew. Honeydew can serve as secondary inoculum if splash- or insectdispersed to uninfected flowers within a season. Losses due to ergot are incurred at various stages of grass seed production. Direct yield losses occur due to seed replacement and highly infested seed lots may be rejected from certification, which reduces economic return. Infested seed lots are often cleaned several times to remove ergot, which results in the loss of seed and increased time and labor costs. High amounts of sticky honeydew in the field can also hinder harvesting operations. Infested seed screenings, the plant material left over from the seed cleaning process, cannot be pelletized and sold as feed due to the presence of ergot alkaloids, which are toxic to humans and livestock (Craig et al. 2015; Shelby 1999).

Management of ergot is especially difficult in grass seed production systems in the Columbia Basin of eastern Oregon. The perennial nature of many grass seed cropping systems in the area precludes the use of certain management tactics such as annual crop rotation and burying sclerotia through tillage. Open field burning, which can reduce the viability of sclerotia, is usually not performed due to increasing concerns over the impacts of field burning on the environment and human health (Chastain et al. 1997). In addition to using ergot-free seed for planting, controlling weedy and volunteer hosts, and rotating with nonhosts, growers typically make applications of fungicides during anthesis (Walenta et al. 2015). Fungicide applications intend to protect the ovaries of grass flowers, the only susceptible part of the plant, from infection. Consequently, the timing and placement of initial and subsequent fungicide applications are important factors that contribute to their efficacy. In the U.S. Pacific Northwest, approximately $95 \%$ of grass seed growers utilize fungicides for ergot management and growers make one to four applications depending on the season and pathogen pressure (Walenta et al. 2015). Knowledge about the presence or absence of pathogen inoculum may allow growers to make more informed decisions regarding fungicide applications. This is not only important economically, given the large scale nature of grass seed production 
in the area, but also from a fungicide resistance management strategy since the same active ingredients can also be used to manage powdery mildew and rust in grass seed crops in Oregon and other states (Pscheidt and Ocamb 2016).

Ergot can be a persistent problem in many areas where grass seed is produced. However, the incidence and severity of ergot epidemics in grass grown for seed can vary among and within growing regions and years (Alderman 1991; Alderman et al. 1996; Alderman et al. 1998; Alderman et al. 2010; Butler et al. 2001). Cool-season grasses are grown in a wide range of climates in Oregon ranging from the high rainfall conditions typical in the Willamette Valley ( 0 to $>240 \mathrm{~m}$ above sea level and 100 to $200 \mathrm{~cm}$ annual precipitation depending on location), semiarid high elevation deserts in central Oregon (approximately $740 \mathrm{~m}$ above sea level and $24 \mathrm{~cm}$ annual precipitation), semiarid low elevation production regions in the Columbia Basin (approximately $180 \mathrm{~m}$ above sea level and $20 \mathrm{~cm}$ annual precipitation), and high mountain valleys in northeastern Oregon (approximately $830 \mathrm{~m}$ above sea level and $42 \mathrm{~cm}$ annual precipitation). Differences in ergot severity among cool-season grass species and cultivars can occur among these regions and in some years the timing of ascospore release by the fungus may not coincide with host anthesis, which is the only period of host susceptibility (Cunfer et al. 1975; Walenta et al. 2008). The timing and duration of ascospore release by $C$. purpurea, which is likely affected by the environment and other factors, would influence the amount of initial inoculum present during anthesis and consequently the incidence and severity of ergot epidemics during the growing season.

Previous studies have investigated the phenology and aerobiology of $C$. purpurea ascospores production in perennial ryegrass and Kentucky bluegrass seed production fields in Oregon (Alderman 1993; Alderman et al. 2015; Walenta et al. 2008). In the Willamette Valley, ascospore release in the field typically occurred 2 to 3 days after a rain event and was not correlated with air temperature or relative humidity (Alderman 1993). This is consistent with a previous study which concluded that soil moisture is required for sclerotia germination and capitula formation (Markhasseva 1936). In the semiarid Columbia Basin of eastern Oregon, grass seed production fields are irrigated frequently and moisture is not limiting, so air or soil temperatures may be more important factors that influence sclerotia germination and the release of ascospores. The Columbia Basin is a relatively new production area for perennial ryegrass seed and therefore there is a need to develop a better understanding of the weather conditions that contribute to $C$. purpurea ascospore occurrence in Columbia Basin production systems. New information could help predict ascospore release which in turn could improve the timing of fungicide applications and overall ergot management. The objectives of this study were to: (i) determine the seasonal timing and concentration of $C$. purpurea ascospores in fields of perennial ryegrass grown for seed in the Columbia Basin of eastern Oregon; (ii) identify weather factors that contribute to ascospore occurrence; and (iii) develop and validate a model that can be used to predict ascospore incidence in perennial ryegrass fields located in the Columbia Basin. Preliminary results have been presented (Dung et al. 2014).

\section{Materials and Methods}

Spore sampling. Spore sampling was conducted in three naturally infested, commercial, perennial ryegrass fields and two artificially infested, perennial ryegrass plots between 2013 and 2015. The three commercial, perennial ryegrass fields were located in the Columbia Basin in Umatilla Co., OR. Fields A and B were 50 ha and planted in the fall of 2011. Field A (cv. Pavilion) was located on a Quincy loamy fine sand (66.7\%)-Winchester-Quinton complex (17.0\%)Shano very fine sandy loam (15.9\%)-Burke silt loam (0.5\%) soil at an elevation of $\sim 271 \mathrm{~m}$ and was sampled in 2013 and 2014. Field B (cv. Top Hat II) was sampled in 2013 and located at 217-m elevation on a Shano very fine sandy loam (80.3\%)-Taunton fine sandy loam (6.1\%)-Adkins fine sandy loam (5.3\%)-Quincy loamy fine sand (4.9\%)-Quincy fine sand (3.4\%) soil. Field C (cv. Pavilion) was sampled in 2015 and located at 204 m elevation on a Winchester-Quinton complex (78.2\%)-Quincy loamy fine sand (21.8\%) soil. The two artificially infested perennial ryegrass plots were located on an Adkins fine sandy loam (100\%) at the Hermiston Agricultural Research and Extension Center (HAREC) in Hermiston, OR (elevation $186 \mathrm{~m}$ ), and sampled in 2014 and 2015. Plots in both years were 0.09 ha and planted to a mixture of 12 perennial ryegrass cultivars in August of 2013 and 2014. Plots were artificially infested in October of 2013 and 2014 with approximately 10,000 sclerotia collected from perennial ryegrass seed lots harvested the same year. Sclerotia were evenly distributed across the plot surface by hand. All fields and plots were subjected to similar cultural practices and irrigated using center pivot irrigation as is customary in the region.

Hirst-type Burkard 7-day recording volumetric spore samplers (Burkard Scientific Ltd., Uxbridge, Middlesex, UK), which were calibrated to continuously sample air at 10 liters/min, were used to collect airborne ascospores of $C$. purpurea. A spore sampler was placed in field A from 3 April to 19 June 2013 and 22 April to 27 June 2014. In 2013, spores were sampled from field B from 3 April to 15 June. Field C was sampled between 2 April and 22 June 2015. Spore samplers were placed in artificially-infested plots at HAREC between 11 April and 23 June 2014 and between 4 April and 22 June 2015. These time periods were selected based on data from previous spore trapping efforts in this region and correspond with the typical flowering period of perennial ryegrass seed crops in the region (Alderman et al. 2015). Spore samplers were placed approximately $150 \mathrm{~m}$ from the field border and powered with a 12 volt battery, which was replaced every 7 days. The air intake orifice was situated 0.4 to $0.6 \mathrm{~m}$ above ground level and spore traps were calibrated every 7 days to ensure they were sampling air at 10 liters $/ \mathrm{min}$. Spores were impacted onto clear Melinex tape coated with silicone grease used with Rotorod samplers (Ted Brown Associates, Los Altos, CA). Spore trap tapes were collected and replaced weekly, processed, and analyzed as described by Alderman (1993). Briefly, tapes were cut into daily segments and divided into hourly partitions by gently pressing the edge of a razor blade to the tape surface, using the trimming block provided by the manufacturer as a reference. Tapes were mounted onto microscope slides and ascospores were stained with aniline blue (30 mg aniline blue, $20 \mathrm{ml}$ deionized water, $10 \mathrm{ml}$ glycerol, and $10 \mathrm{ml}$ lactic acid) before covering the tapes with a cover glass. For each 24-h period (12:00 A.M. to 11:59 P.M.) the number of ascospores trapped per hour was counted under a microscope at $300 \times$ magnification and summed to determine daily ascospore counts. Ascospores of $C$. purpurea were identified with the aid of reference slides containing $C$. purpurea ascospores.

Weather data collection. The collected weather data included daily minimum, maximum, and mean of air and soil temperatures $\left({ }^{\circ} \mathrm{C}\right)$, mean daily relative humidity $(\%)$, and mean daily dew point $\left({ }^{\circ} \mathrm{C}\right)$. Weather data were compiled from the HRMO weather station in the AgriMet Northwest Cooperative Agricultural Weather Network, which is located at the HAREC. The HRMO weather station was located approximately $19.4 \mathrm{~km}$ from field A, $13.8 \mathrm{~km}$ from field $\mathrm{B}, 18.2 \mathrm{~km}$ from field $\mathrm{C}$, and within $3.0 \mathrm{~km}$ from the artificially infested plots at HAREC.

The AgriMet Northwest Cooperative Agricultural Weather Network utilized a Campbell Scientific Data Logger Model CR1000 (Campbell Scientific, Inc., Logan, UT) which was programmed to read sensors at 15-min intervals. Air temperature and relative humidity were measured using a Rotronic HygroClip HC2-S3 (Rotronic Instrument Corp., Hauppauge, NY) equipped with a multiplate radiation shield (Model 41002P; R. M. Young Company, Traverse City, MI). Soil temperature was measured in a plot of mixed grass and weeds at a depth of $5 \mathrm{~cm}$ using a thermistor (Model 44030; YSI Inc., Yellow Springs, OH). Weather variables were measured during a 24-h period beginning at 00:00 h. Degree days and cumulative degree days were calculated to determine if accumulated degree days could be used to predict the onset of $C$. purpurea ascospore occurrence. Degree days were calculated for air and soil temperatures using the single-sine method (Zalom et al. 1983). A base temperature of $10^{\circ} \mathrm{C}$ and an upper threshold temperature of $25^{\circ} \mathrm{C}$ was used for degree day calculations based on previous studies (Mitchell and Cooke 1968; Uppala et al. 2011; Uppala et al. 2016). Accumulation of 
degree days began on 1 January using data collected from the HRMO weather station. Soil temperature data were not available from the HRMO weather station between 6 June and 19 June 2013.

Statistical analyses and model development. Data from both sites in each year were combined and correlation analysis was performed using PROC CORR in SAS to identify significant $(P<$ $0.05)$ correlations between daily ascospore concentrations and weather variables collected from the HRMO weather station. Spearman's rank correlation coefficients were calculated due to the nonparametric nature of the data. The potential for multicollinearity among weather variables was also examined using correlation analysis. Local regression surfaces were estimated using a nonparametric method (PROC LOESS) in SAS 9.4 (SAS Institute Inc., Cary, NC) to identify trends in daily ascospore concentrations against weather variables (Cleveland et al. 1988; Granke and Hausbeck 2010).

Daily ascospore counts were converted to a binary dependent variable for the presence (1) or absence (0) of ascospores. Univariate analysis was used to compare distributions of weather variables for days when ascospores were present or absent and box-and-whisker plots were constructed using PROC BOXPLOT in SAS to visualize distributions of weather variables (Fidanza et al. 1996). Statistical comparisons of distributions were conducted using the nonparametric Kolmogorov-Smirnov test (PROC NPAR1WAY). A Bonferroni correction $(P=0.05 / 14)$ was used to account for multiple comparisons at an overall $P$-value of 0.05 . Quantiles, median and mean values for weather variables on days when at least one $C$. purpurea ascospore was observed were calculated using PROC UNIVARIATE in SAS. Results from correlation, nonparametric regression, and univariate analyses were used to identify weather variables associated with ascospore events and develop environmental favorability indices (EFIs) (Fidanza et al. 1996; Kaminski et al. 2007; Nutter et al. 1983). Single-factor EFIs were developed using individual weather variables and point values were assigned to each weather variable based on visual inspection of local regression surfaces and the results
A

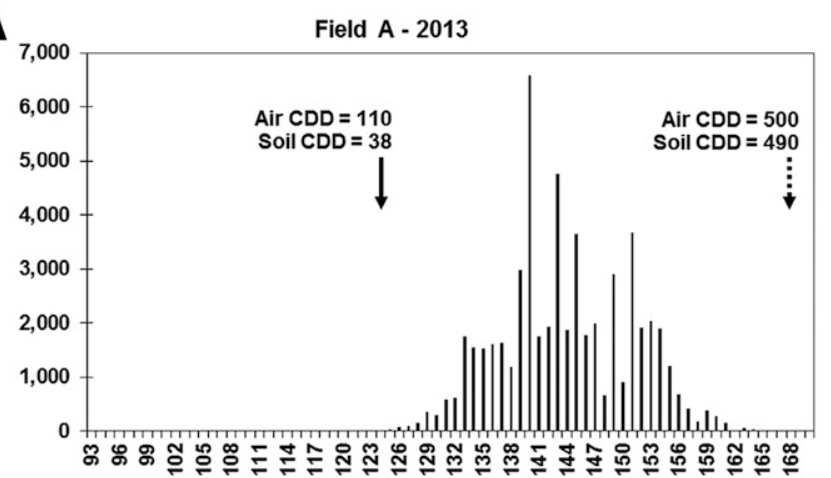

C

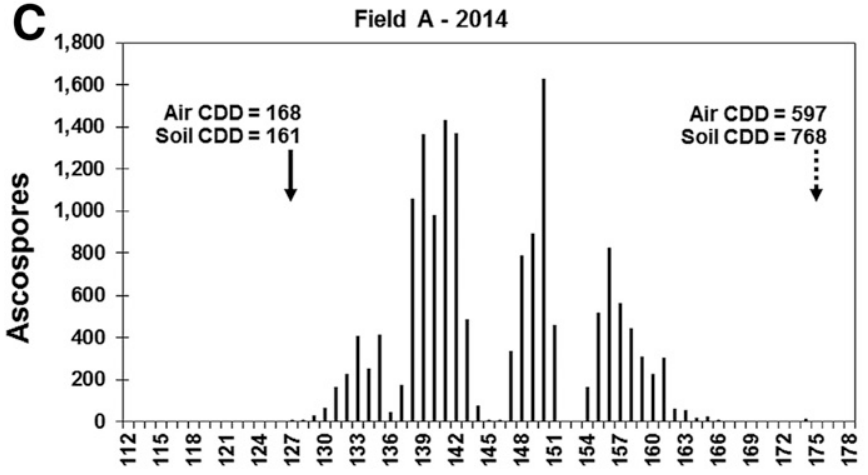

B

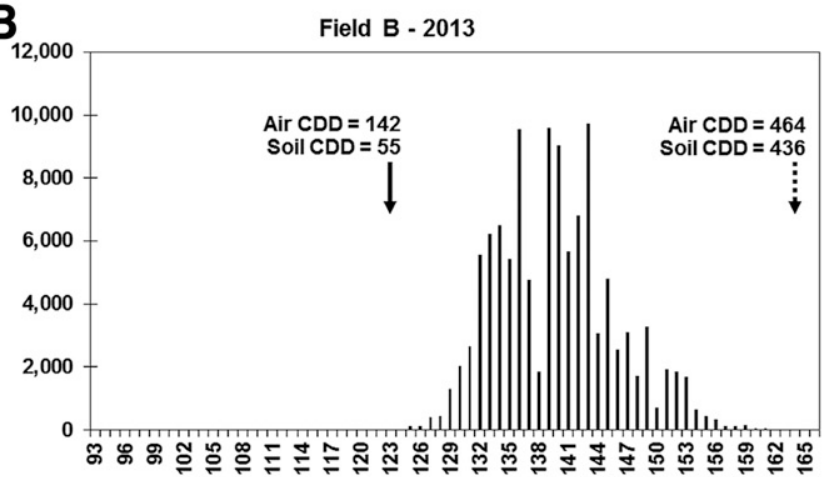

D

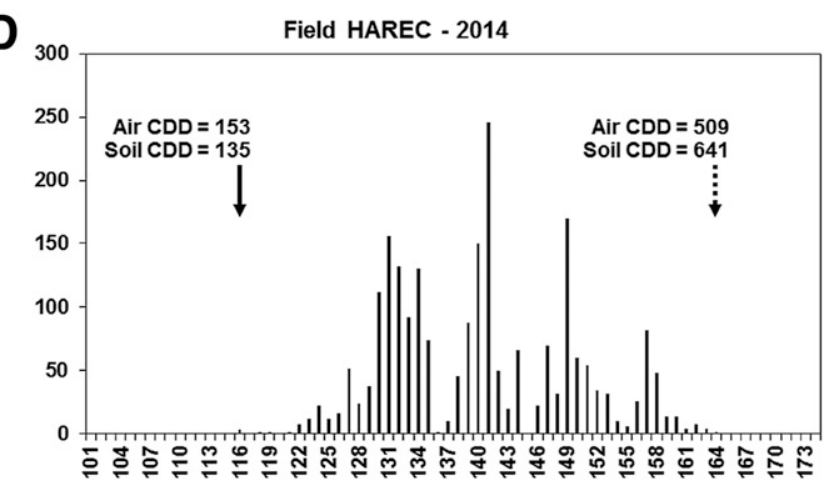

$\mathbf{F}$

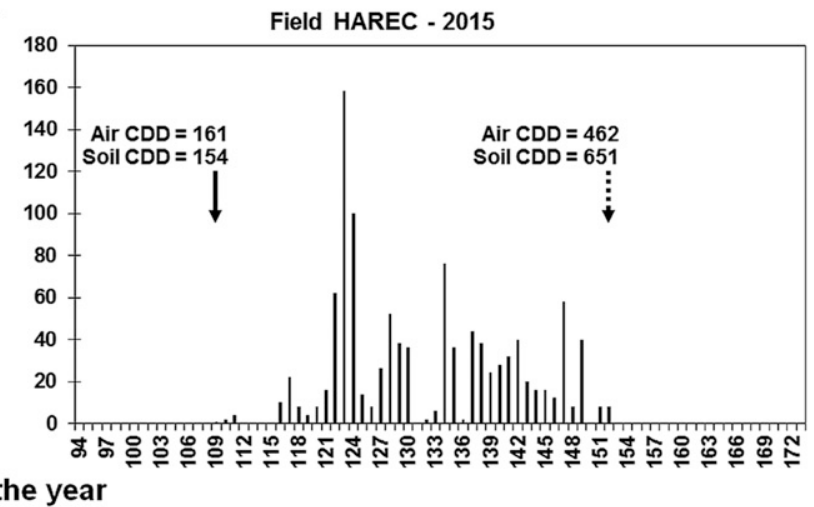

Fig. 1. Total Claviceps purpurea ascospores trapped in: A, commercial perennial ryegrass seed field A in 2013; B, commercial perennial ryegrass seed field B in 2013; C, commercial perennial ryegrass seed field A in 2014; D, artificially infested perennial ryegrass plots at the Hermiston Agricultural Research and Extension Center (HAREC) in 2014; E, commercial perennial ryegrass seed field C in 2015; and F, artificially infested perennial ryegrass plots at the HAREC in 2015. All fields were located in Umatilla Co., OR. Air and soil cumulative degree day (CDD) values are presented for the first occurrence of ascospores (solid arrows) and the last occurrence of ascospores (dotted arrows). Weather data were collected from the Oregon AgriMet HRMO weather station, which was located at the HAREC in Umatilla Co., OR, and approximately 3.0 to $19.4 \mathrm{~km}$ from the field sites. Air and soil CDD values were calculated beginning on January 1 using the single-sine method with upper and lower thresholds of 25 and $10^{\circ} \mathrm{C}$, respectively. 
of univariate analysis (Kaminski et al. 2007; Krause and Massie 1975). The first and third quantiles for each weather variable, as determined by univariate analysis, were used as the lower and upper thresholds in the single-factor EFI models, respectively. Analyses of ascospore events used the binary dependent variable described above. Chi-square $\left(\chi^{2}\right)$ tests (PROC FREQ in SAS) were performed to determine the accuracy of each EFI. The single factor EFIs were combined into cumulative EFI models based on air temperatures $\left(\mathrm{EFI}_{\mathrm{Air}}\right)$ and soil temperatures $\left(\mathrm{EFI}_{\text {Soil }}\right)$. The accuracy of each cumulative EFI model was determined as described above.

Cumulative EFI models were validated using spore trap data that was not used in the development of the model. The spore trap data used for validation was collected in 2008, 2010, and 2012 as previously described for the spore trap data used for model development. Spores were trapped in three different 50 ha commercial perennial ryegrass fields (cv. Pavilion); the three fields were planted and managed by the same grower as all other commercial fields used in this study. Spore trap data were also collected in 2010 from a 0.04-ha perennial ryegrass plot located at HAREC that was artificially infested as described above.

\section{Results}

In 2013, a total of 56,144 ascospores and 114,525 ascospores were captured in field A and field B, respectively. The first occurrence of ascospores in 2013 was on 24 April in field A and on 30 April in field B. There were 54 ascospore events (days with at least one spore trapped) in field $\mathrm{A}$ and 47 ascospore events in field $\mathrm{B}$, with the last occurrence of ascospores on 19 June in field A and 15 June in field B. The first occurrence of ascospores in 2014 was on 30 April in field A and 26 April at HAREC, and a total of 16,237 ascospores and 2,260 ascospores were captured in field A and at HAREC, respectively. Ascospore production continued until 24 June in field A and 13 June at HAREC, with 48 and 47 ascospore events in these respective fields. The first ascospores of 2015 were captured on 19 April and 22 April at HAREC and field C, respectively; a total of 1,083 were captured at HAREC and 38,917 ascospores were captured in field C. In 2015, a total of 38 ascospore events occurred at HAREC and 50 ascospore events were recorded in field $\mathrm{C}$, with the last ascospores captured on 1 June at HAREC and on 12 June in field $\mathrm{C}$. The number of ascospores captured in a single day ranged from 0 to 9,723 , and several peaks of high ascospore production (>1,000 ascospores/day) were observed in all three years (Fig. 1). The cumulative air degree days at first ascospore occurrence ranged between 102 and 179 over the three years, while cumulative soil degree days ranged between 38 and 183 (Fig. 1). Daily ascospore production tended to decline after June 10 in all three years (Fig. 1).
Minimum soil temperature and daily soil degree days were significantly correlated with ascospore concentration in all three years (Table 1). Maximum and mean air and soil temperatures, daily air degree days, cumulative air and soil degree days, mean daily relative humidity, and mean daily dew point temperature were significantly correlated with ascospore concentration in 2 of 3 years (Table 1 ). When all data were combined across years and sites, all weather variables with the exception of mean daily relative humidity were significantly correlated with ascospore concentration (Table 1). Most of the weather variables exhibited positive correlations with ascospore concentration (Table 1). Varying degrees of multicollinearity were detected among the temperature variables in all three years (data not shown).

Box-and-whisker plots and nonparametric regression identified several trends in ascospore concentrations among the weather variables included in this study (Figs. 2 and 3). Univariate analysis was used to calculate the quantiles, median and mean values for days when ascospores were present and confirmed the trends observed in the box-and-whisker plots and nonparametric regression (Table 2). When data from all three years were combined, the distributions of all weather variables were significantly different for days when $C$. purpurea ascospores were captured compared with days when ascospores were not captured $(P \leq 0.0036)$ with the exception of mean daily relative humidity (Table 2 ). Most ascospores (75.4\% of total) were captured when minimum soil temperatures were between 16.2 and $20.4^{\circ} \mathrm{C}$ and over $67 \%$ of the total ascospores trapped were observed when minimum air temperatures were between 6.8 and $12.4^{\circ} \mathrm{C}$. Additionally, $64 \%$ of ascospores were trapped when daily mean dew point was between 3.7 and $8.2^{\circ} \mathrm{C}$. Mean air temperatures between 14.6 and $20.2^{\circ} \mathrm{C}$ and mean soil temperatures between 17.9 and $22.6{ }^{\circ} \mathrm{C}$ were also associated with $C$. purpurea ascospore occurrence. Over the course of the three seasons, $94.0 \%$ of the total ascospores were captured when cumulative air degree days were between 230.1 and 403.7 (Fig. 2; Table 2).

Single-factor EFI models were developed using the individual weather variables minimum air temperature $\left(\right.$ Air $\mathrm{T}_{\min }$ ), maximum air temperature (Air $\mathrm{T}_{\max }$ ), mean air temperature (Air $\mathrm{T}_{\text {mean }}$ ), daily air degree days (Air $\mathrm{T}_{\mathrm{DD}}$ ), cumulative air degree days (Air $\mathrm{T}_{\mathrm{CDD}}$ ), minimum soil temperature (Soil $\mathrm{T}_{\min }$ ), maximum soil temperature (Soil $\mathrm{T}_{\max }$ ), mean soil temperature (Soil $\mathrm{T}_{\text {mean }}$ ), daily soil degree days (Soil $\mathrm{T}_{\mathrm{DD}}$ ), cumulative soil degree days (Soil $\mathrm{T}_{\mathrm{CDD}}$ ), mean relative humidity (Relative humidity mean $_{\text {) }}$ and mean dew point (Dew point $_{\text {mean }}$ ) (Table 3). When used to predict the occurrence of at least one ascospore from 2013 to 2015, all single-factor EFIs resulted in significant $\chi^{2}$ values $(P<0.05)$ and ranged in accuracy from 39.5 to $72.8 \%$, with the exception of Dew point mean $_{\text {in }} 2014\left(\chi^{2}=2.62\right.$; $P=0.11)$ and Relative humidity mean $_{\text {in }} 2015\left(\chi^{2}=0.21 ; P=0.65\right)$

Table 1. Spearman rank correlation coefficients between daily Claviceps purpurea ascospore concentrations in commercial fields of perennial ryegrass and daily weather variables in 2013,2014, 2015, and all three years combined in Umatilla Co., OR ${ }^{\mathrm{a}}$

\begin{tabular}{lcccc}
\hline & \multicolumn{3}{c}{ Daily $\boldsymbol{C}$. purpurea ascospore concentrations } \\
\cline { 2 - 5 } Daily weather variable & $\mathbf{2 0 1 3}(\boldsymbol{n}=\mathbf{1 5 2})$ & $\mathbf{2 0 1 4}(\boldsymbol{n}=\mathbf{1 4 1})$ & $\mathbf{2 0 1 5}(\boldsymbol{n}=\mathbf{1 6 2})$ & Combined $(\boldsymbol{n}=\mathbf{4 5 5})$ \\
\hline Minimum air temperature $\left({ }^{\circ} \mathrm{C}\right)$ & $0.42^{* * *}$ & 0.16 & 0.14 & $0.25^{* * *}$ \\
Maximum air temperature $\left({ }^{\circ} \mathrm{C}\right)$ & $0.46^{* * *}$ & $0.37^{* * *}$ & 0.07 & $0.29^{* * *}$ \\
Mean air temperature $\left({ }^{\circ} \mathrm{C}\right)$ & $0.47^{* * *}$ & $0.33^{* * *}$ & 0.13 & $0.30^{* * *}$ \\
Air DD & $0.44^{* * *}$ & $0.32^{* * *}$ & 0.14 & $0.29^{* * *}$ \\
Air CDD & $0.67^{* * *}$ & $0.19^{*}$ & 0.10 & $0.29^{* * *}$ \\
Minimum soil temperature $\left({ }^{\circ} \mathrm{C}\right)$ & $0.66^{* * *}$ & $0.32^{* * *}$ & $0.16^{*}$ & $0.33^{* * *}$ \\
Maximum soil temperature $\left({ }^{\circ} \mathrm{C}\right)$ & $0.66^{* * *}$ & $0.40^{* * *}$ & 0.13 & $0.19^{* * *}$ \\
Mean soil temperature $\left({ }^{\circ} \mathrm{C}\right)$ & $0.66^{* * *}$ & $0.38^{* * *}$ & 0.15 & $0.26^{* * *}$ \\
Soil DD & $0.66^{* * *}$ & $0.37^{* * *}$ & $0.16^{*}$ & $0.26^{* * *}$ \\
Soil CDD & $0.67^{* * *}$ & $0.19^{*}$ & 0.10 & $0.21^{* * *}$ \\
Mean relative humidity $(\%)$ & -0.03 & $-0.25^{* *}$ & $0.28^{* *}$ & 0.02 \\
Mean dew point $\left({ }^{\circ} \mathrm{C}\right)$ & $0.52^{* * *}$ & 0.15 & $0.37^{* * *}$ & $0.38^{* * *}$ \\
\hline
\end{tabular}

${ }^{a}$ Weather data were collected from the Oregon AgriMet HRMO weather station, which was located at the Hermiston Agricultural Research and Extension Center (HAREC) in Umatilla Co., OR, and approximately 3.0 to $19.4 \mathrm{~km}$ from the field sites.

${ }^{b}$ Values without a * were not significant at $P=0.05 ; *=$ significant at $P<0.05 ; * *$ significant at $P<0.01$; and $* * *=$ significant at $P \leq 0.0001$.

${ }^{c}$ Air and soil degree days (DD) and cumulative degree days (CDD) were calculated using the single-sine method with upper and lower thresholds of 25 and $10^{\circ} \mathrm{C}$, respectively. CDD were calculated beginning on 1 January. 

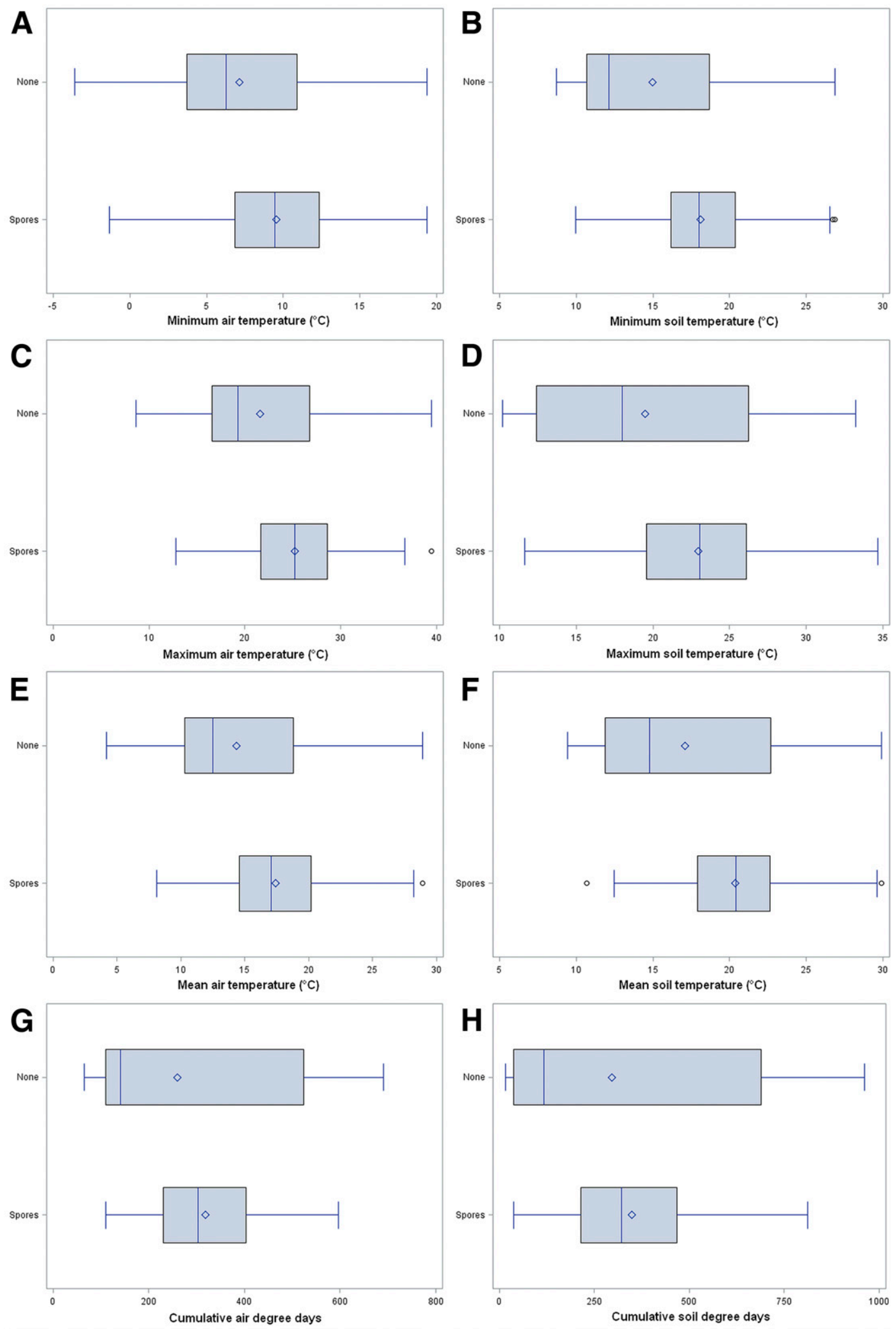

Fig. 2. Box-and whisker plots showing the distributions of weather variables on days when Claviceps purpurea ascospores were observed (bottom boxes) and not observed (top boxes). Weather variables include: $\mathbf{A}$, minimum air temperature $\left({ }^{\circ} \mathrm{C}\right) ; \mathbf{B}$, minimum soil temperature $\left({ }^{\circ} \mathrm{C}\right) ; \mathbf{C}$, maximum air temperature $\left({ }^{\circ} \mathrm{C}\right) ; \mathbf{D}$, maximum soil temperature $\left({ }^{\circ} \mathrm{C}\right) ; \mathbf{E}$, mean air temperature $\left({ }^{\circ} \mathrm{C}\right)$; $\mathbf{F}$, mean soil temperature $\left({ }^{\circ} \mathrm{C}\right)$ : $\mathbf{G}$, cumulative air degree days; and $\mathbf{H}$, cumulative soil degree days. Claviceps purpurea ascospores were quantified in three naturally-infested commercial perennial ryegrass fields and two artificially-infested perennial ryegrass plots located in Umatilla Co., OR, between 2013 and 2015 . Weather data were collected from the Oregon AgriMet HRMO weather station, which was located at the HAREC in Umatilla Co., OR, and approximately 3.0 to $19.4 \mathrm{~km}$ from the field sites. Air and soil degree days (DD) and cumulative degree days (CDD) were calculated beginning on 1 January using the single-sine method and with upper and lower thresholds of 25 and $10^{\circ} \mathrm{C}$, respectively. Rectangles represent the first quartiles (left side of boxes), medians (center lines), and third quartiles (right side of boxes) of the data. Minimum and maximum extremes of the distributions are represented by the left and right whiskers, respectively, with outliers presented as open circles. Mean values are indicated by diamonds. 
(Table 3). When data from all three years were combined, all five single-factor EFIs resulted in significant $\chi^{2}$ values and ranged in accuracy from 55.4 to $68.4 \%$ (Table 3 ).

The five air and soil temperature variables were integrated into cumulative $\mathrm{EFI}_{\mathrm{Air}}$ and $\mathrm{EFI}_{\text {Soil }}$ models, respectively. An $\mathrm{EFI}_{\mathrm{Air}}$ value $\geq 1$ predicted the occurrence of ascospore with an accuracy of $75.2 \%$ accuracy $\left(\chi^{2}=95.50 ; P<0.0001\right)$ while an $\mathrm{EFI}_{\text {Air }}$ value $\geq 2$ was able to accurately predict the occurrence ascospores $69.9 \%$ of the time $\left(\chi^{2}=\right.$ $76.11 ; P<0.0001)$ (Table 4). An $\mathrm{EFI}_{\text {Soil }}$ value $\geq 1$ provided the best predictive ability ( $77.8 \%$ accuracy) for the occurrence of at least one
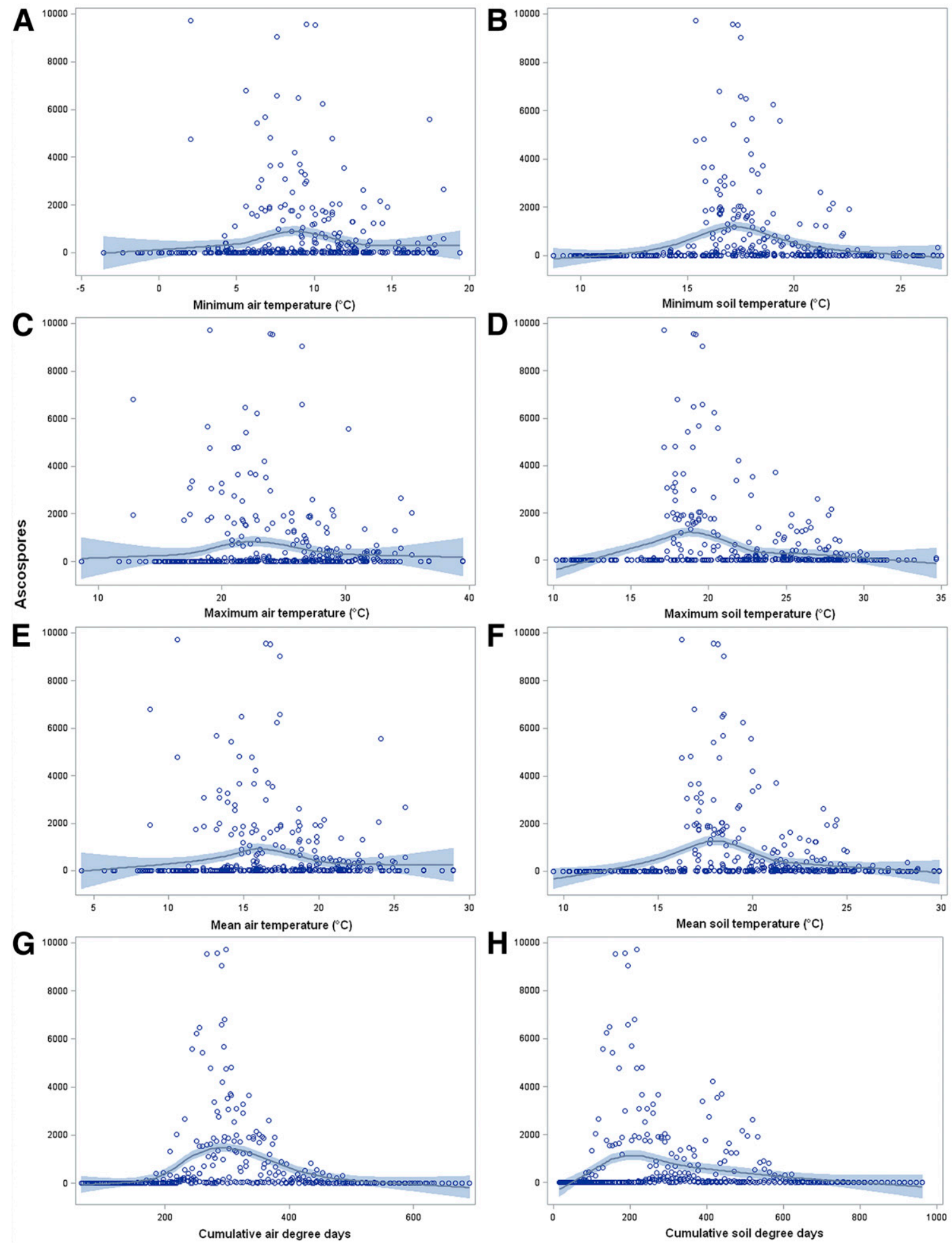

Fig. 3. Daily concentrations of Claviceps purpurea ascospores (open circles) fit to weather variables with a nonparametric local regression curve. Weather variables include: $\mathrm{A}$, minimum air temperature $\left({ }^{\circ} \mathrm{C}\right) ; \mathbf{B}$, minimum soil temperature $\left({ }^{\circ} \mathrm{C}\right) ; \mathbf{C}$, maximum air temperature $\left({ }^{\circ} \mathrm{C}\right) ; \mathbf{D}$, maximum soil temperature $\left({ }^{\circ} \mathrm{C}\right) ; \mathbf{E}$, mean air temperature $\left({ }^{\circ} \mathrm{C}\right) ; \mathbf{F}$, mean soil temperature $\left({ }^{\circ} \mathrm{C}\right)$; G, cumulative air degree days; and $\mathbf{H}$, cumulative soil degree days. Shaded areas represent the $95 \%$ confidence band. Claviceps purpurea ascospores were quantified in three naturally-infested commercial perennial ryegrass fields and two artificially-infested perennial ryegrass plots located in Umatilla $\mathrm{Co}$., OR, between 2013 and 2015. Weather data were collected from the Oregon AgriMet HRMO weather station, which was located at the HAREC in Umatilla Co., OR, and approximately 3.0 to $19.4 \mathrm{~km}$ from the field sites. Air and soil degree days $(\mathrm{DD})$ and cumulative degree days $(\mathrm{CDD})$ were calculated beginning on 1 January using the single-sine method and with upper and lower thresholds of 25 and $10^{\circ} \mathrm{C}$, respectively. 
ascospore $\left(\chi^{2}=137.88 ; P<0.0001\right)$, while an $\mathrm{EFI}_{\text {Soil }}$ value $\geq 2$ predicted the occurrence of ascospores with an accuracy of $70.8 \%\left(\chi^{2}=101.87\right.$; $P<0.0001$ ) (Table 4). Among individual years, an $\mathrm{EFI}_{\text {Air }}$ value $\geq 1$ was between 71.6 and $79.6 \%$ accurate while an $\mathrm{EFI}_{\text {Soil }}$ value $\geq 1$ ranged in accuracy from 72.8 to $87.5 \%$. When validated against historical spore

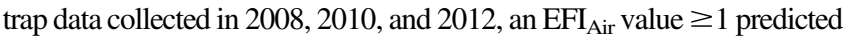
the occurrence of ascospores with an accuracy of 74.6 to $91.2 \%$ while an $\mathrm{EFI}_{\text {Soil }}$ value $\geq 1$ was 70.8 to $85.3 \%$ accurate (Table 5). When all three years of historical data were combined $\mathrm{EFI}_{\text {Air }}$ and $\mathrm{EFI}_{\text {Soil }}$ values $\geq 1$ exhibited an accuracy of 79.8 and $74.6 \%$, respectively (Table 5).

\section{Discussion}

The EFI models developed in this study predicted the occurrence of $C$. purpurea ascospores with an accuracy of up to $77.8 \%$, and were up to $79.8 \%$ accurate when validated against three years of historical spore trap and weather data. Among the two models $\left(\mathrm{EFI}_{\mathrm{Air}}, \mathrm{EFI}_{\text {Soil }}\right)$ the most accurate predictions occurred when EFI values were $\geq 1$ or 2 . An EFI value $\geq 3$ tended to produce a greater number of false negative predictions (incorrectly predicting that ascospores would not be present), while an EFI value of 0 resulted in more false positive predictions (incorrectly predicting that ascospores would be present). Increasing the threshold from one to 10 or 100 ascospores did not consistently improve the predictive ability of the EFI models and increased the number of false negative predictions (data not shown). In the case of ergot in perennial ryegrass seed production, false negatives should be avoided since the consequences of not applying protectant fungicides can potentially result in severe epidemics.

Single factor EFI models based on the individual weather variables predicted ascospore occurrence in 2013, 2014, and 2015 with an accuracy 55.4 to $68.4 \%$ when data from all 3 years were combined. However, among individual years the accuracy of the single factor EFI models ranged between 39.5 and $72.8 \%$. In addition, the single factor models were only 34.2 to $82.4 \%$ accurate when validated against historical spore trap data from 2008, 2010, and 2012 and ranged in accuracy from 36.6 to $71.4 \%$ accurate when data from all three years were combined (data not shown). In most cases, single factor EFI models resulted in a large number of false negatives (17.6 to $61.8 \%)$ when validated against historical spore trap data (data not shown). Although a high degree of multicollinearity was observed among the individual air and soil temperature factors (data not shown), combining these factors into cumulative EFI models improved their predictive ability.

Daily ascospore concentration was positively correlated with minimum soil temperature and daily soil degree days for all three years individually and combined. Maximum air and soil temperature, mean air and soil temperature, daily air degree days, and cumulative air and soil degree days were positively correlated with daily ascospore concentrations in 2013, 2014, and when all three years were combined. Relatively few weather variables were significantly correlated with daily ascospore concentration in 2015 compared with the previous two years. Other factors that were not included in this study, such as irrigation or precipitation events, wind strength and direction, and soil moisture, may have been important factors related to the production of C. purpurea ascospores in 2015.

Since $C$. purpurea sclerotia overwinter in the soil in perennial grass seed fields and grassy field borders, soil temperature, soil moisture, and other soil factors are likely to influence the timing and duration of capitula production in the spring. However, other factors such as air temperature and dew point may be important determinants associated with the longevity of capitula and the release of ascospores from perithecia after capitula emerge from the soil. Although air temperature parameters often resulted in lower correlation coefficients than their corresponding soil temperature parameters, the $\mathrm{EFI}_{\text {Air }}$ model performed similarly to the $\mathrm{EFI}_{\text {Soil }}$ model, suggesting that both air and soil conditions play important roles in C. purpurea ascospore production and dispersal. Dew point was also positively correlated with ascospore concentration in 2013, 2015, and all three years combined. Dew point has been found to be an important factor contributing to high spore concentrations of other fungi (Burch and Levetin 2002; Troutt and Levetin 2001) but the inclusion of dew point in the EFI models did not improve their predictive ability in this study (data not shown).

Nonparametric regression and univariate analysis identified several trends that were associated with the occurrence of $C$. purpurea ascospores. For instance, minimum air temperatures between 6.8 and $12.4^{\circ} \mathrm{C}$ were associated with peak ascospore production and ascospore production was greatest when mean air temperatures were between 14.6 and $20.2^{\circ} \mathrm{C}$. These results agree with a previous study by Alderman (1993), who observed that the abundance of ascospores increased as air temperature increased from 5 to $20^{\circ} \mathrm{C}$ in the Willamette Valley of Oregon. These results are also consistent with other studies performed under controlled conditions which concluded that the highest percentage of $C$. purpurea sclerotia germination occurred at incubation temperatures between 10 and $25^{\circ} \mathrm{C}$ and germination was reduced at air temperatures below $5^{\circ} \mathrm{C}$ and above $25^{\circ} \mathrm{C}$, with $15^{\circ} \mathrm{C}$ being optimal for germination (Mitchell and Cooke 1968; Uppala et al. 2011; Uppala et al. 2012; Uppala et al. 2016). In this study, most ascospores were trapped when minimum soil temperatures

Table 2. Quantiles, median, and mean values for weather variables on days when at least one Claviceps purpurea ascospore was observed between 2013 and 2015 in Umatilla Co., OR, the percentage of total ascospores trapped between the first and third quantiles, and $P$-values from Kolmogorov-Smirnov tests used to determine if the distributions of weather variable values on days when at least one $C$. purpurea ascospore was observed were the same as the distributions of weather variable values on days when no $C$. purpurea ascospores were observed ${ }^{\mathrm{a}}$

\begin{tabular}{lcccrcr}
\hline Variable & First quantile & Median & Third quantile & Mean & Ascospores trapped (\% total) & Kolmogorov-Smirnov $^{\mathbf{b}}$ \\
\hline Minimum air T $\left(\mathrm{C}^{\circ}\right)$ & 6.8 & 9.4 & 12.4 & 9.6 & 67.6 & $<0.0001$ \\
Maximum air T $\left(\mathrm{C}^{\circ}\right)$ & 21.7 & 25.2 & 28.6 & 25.2 & 52.6 & $<0.0001$ \\
Mean air T $\left(\mathrm{C}^{\circ}\right)$ & 14.6 & 17.0 & 20.2 & 17.4 & 59.2 & $<0.0001$ \\
Air DD & 5.0 & 7.3 & 9.7 & 7.3 & 50.6 & $<0.0001$ \\
Air CDD & 230.1 & 302.1 & 403.7 & 318.8 & 94.0 & $<0.0001$ \\
Minimum soil T $\left(\mathrm{C}^{\circ}\right)$ & 16.2 & 18.0 & 20.4 & 18.1 & 75.4 & $<0.0001$ \\
Maximum soil T $\left(\mathrm{C}^{\circ}\right)$ & 19.6 & 23.1 & 26.1 & 23.0 & 34.7 & $<0.0001$ \\
Mean soil T $\left(\mathrm{C}^{\circ}\right)$ & 17.9 & 20.4 & 22.6 & 20.4 & 59.5 & $<0.0001$ \\
Soil DD & 8.1 & 10.6 & 12.7 & 10.3 & 51.3 & $<0.0001$ \\
Soil CDD & 214.6 & 320.7 & 467.7 & 348.2 & 47.5 & $<0.0001$ \\
Mean relative humidity $(\%)$ & 44.6 & 48.7 & 54.4 & 50.5 & 42.0 & $<.0231$ \\
Mean dew point $\left(\mathrm{C}^{\circ}\right)$ & 3.7 & 5.9 & 8.2 & 5.8 & 64.0 & $<0.0001$ \\
\hline
\end{tabular}

a Weather data were collected from the Oregon AgriMet HRMO weather station, which was located at the HAREC in Umatilla Co., OR, and approximately 3.0 to $19.4 \mathrm{~km}$ from the field sites.

${ }^{\mathrm{b}} P$-values are considered significant at $P \leq 0.0036$ after Bonferroni correction $(P=0.05 / 14)$. Rejection of the null hypothesis implies that the distributions of weather variable values on days when at least one $C$. purpurea ascospore was observed and the distributions of weather variable values on days when no C. purpurea ascospores were observed were different.

${ }^{\mathrm{c}}$ Air and soil degree days (DD) and cumulative degree days (CDD) were calculated using the single-sine method with upper and lower thresholds of 25 and $10^{\circ} \mathrm{C}$, respectively. CDD were calculated beginning on 1 January. 
were between 16.2 and $20.4^{\circ} \mathrm{C}$, maximum soil temperatures were between 19.6 and $26.1^{\circ} \mathrm{C}$, and mean soil temperatures were between 17.9 and $22.6^{\circ} \mathrm{C}$. Markhasseva (1936), in a Russian field study, observed that the most vigorous development of capitula occurred when soil temperatures were between 17.3 and $21.2^{\circ} \mathrm{C}$, with higher soil temperatures resulting in delayed development.
Spore traps captured the first C. purpurea ascospores when cumulative air temperature degree days were between 110 and 179 and cumulative soil temperature degree days were between 38 and 183 at the HRMO weather station. Such a wide range of cumulative degree days associated with the initial appearance of ascospores suggests that cumulative degree days, as calculated in this study, are not useful

Table 3. $\chi^{2}\left(\chi^{2}\right)$ analyses of weather variables used to predict the occurrence of at least one Claviceps purpurea ascospore in 2013, 2014, 2015, and all three years combined in Umatilla Co., $\mathrm{OR}^{\mathrm{a}}$

\begin{tabular}{|c|c|c|c|c|c|c|c|c|}
\hline \multirow[b]{2}{*}{ Weather variable ${ }^{b}$} & \multicolumn{4}{|c|}{2013} & \multicolumn{4}{|c|}{2014} \\
\hline & $x^{2}$ & $\begin{array}{c}\text { Correct } \\
\text { predictions }\end{array}$ & $\begin{array}{c}\text { False } \\
\text { positives }^{c}\end{array}$ & $\begin{array}{c}\text { False } \\
\text { negatives }\end{array}$ & $x^{2}$ & $\begin{array}{c}\text { Correct } \\
\text { predictions }\end{array}$ & $\begin{array}{c}\text { False } \\
\text { positives }\end{array}$ & $\begin{array}{c}\text { False } \\
\text { negatives }\end{array}$ \\
\hline Air $\mathrm{T}_{\min }=6.8$ to $12.4^{\circ} \mathrm{C}$ & 11.47 & $63.8 \%$ & $11.2 \%$ & $25.0 \%$ & 4.88 & $60.3 \%$ & $13.5 \%$ & $26.2 \%$ \\
\hline Air $\mathrm{T}_{\max }=21.7$ to $28.6^{\circ} \mathrm{C}$ & 18.28 & $58.6 \%$ & $2.6 \%$ & $38.8 \%$ & 3.97 & $56.7 \%$ & $11.4 \%$ & $31.9 \%$ \\
\hline Air $\mathrm{T}_{\text {mean }}=14.6$ to $20.2^{\circ} \mathrm{C}$ & 15.30 & $61.2 \%$ & $5.9 \%$ & $32.9 \%$ & 8.56 & $57.5 \%$ & $7.1 \%$ & $35.5 \%$ \\
\hline Air $\mathrm{T}_{\mathrm{DD}}=5.0$ to 9.7 & 17.63 & $61.2 \%$ & $4.6 \%$ & $34.2 \%$ & 12.49 & $63.8 \%$ & $9.2 \%$ & $27.0 \%$ \\
\hline Air $\mathrm{T}_{\mathrm{CDD}}=230.1$ to 403.7 & 44.77 & $70.4 \%$ & $0.0 \%$ & $29.6 \%$ & 21.13 & $59.6 \%$ & $1.4 \%$ & $39.0 \%$ \\
\hline Soil $\mathrm{T}_{\min }=16.2$ to $20.4^{\circ} \mathrm{C}$ & 39.91 & $67.8 \%$ & $0.0 \%$ & $32.2 \%$ & 11.15 & $61.0 \%$ & $7.8 \%$ & $31.2 \%$ \\
\hline Soil $\mathrm{T}_{\max }=19.6$ to $26.1^{\circ} \mathrm{C}$ & 25.58 & $58.6 \%$ & $0.0 \%$ & $41.4 \%$ & 6.60 & $61.7 \%$ & $12.8 \%$ & $25.5 \%$ \\
\hline Soil $\mathrm{T}_{\text {mean }}=17.9$ to $22.6^{\circ} \mathrm{C}$ & 38.76 & $67.1 \%$ & $0.0 \%$ & $32.9 \%$ & 8.08 & $59.6 \%$ & $9.2 \%$ & $31.2 \%$ \\
\hline Soil $\mathrm{T}_{\mathrm{DD}}=8.1$ to 12.7 & 34.36 & $64.5 \%$ & $0.0 \%$ & $35.5 \%$ & 6.67 & $59.6 \%$ & $10.6 \%$ & $29.8 \%$ \\
\hline Soil $\mathrm{T}_{\mathrm{CDD}}=214.6$ to 467.7 & 37.62 & $66.5 \%$ & $0.0 \%$ & $33.6 \%$ & 30.88 & $65.3 \%$ & $0.7 \%$ & $34.0 \%$ \\
\hline Relative humidity $_{\text {mean }}=44.6$ to $54.4 \%$ & 4.01 & $57.2 \%$ & $12.5 \%$ & $30.3 \%$ & 4.37 & $58.9 \%$ & $12.8 \%$ & $28.4 \%$ \\
\hline \multirow[t]{2}{*}{ Dew point $t_{\text {mean }}=3.7$ to $8.2^{\circ} \mathrm{C}$} & 21.51 & $67.8 \%$ & $7.9 \%$ & $24.3 \%$ & $2.62 \mathrm{~ns}$ & $60.3 \%$ & $17.0 \%$ & $22.7 \%$ \\
\hline & & & & & & & \multicolumn{2}{|c|}{ (continued on next page) } \\
\hline
\end{tabular}

a Weather data were collected from the Oregon AgriMet HRMO weather station, which was located at the HAREC in Umatilla Co., OR, and approximately 3.0 to $19.4 \mathrm{~km}$ from the field sites.

b Weather variables: minimum air temperature (Air $\mathrm{T}_{\min }$ ), maximum air temperature (Air $\mathrm{T}_{\max }$ ), mean air temperature (Air $\left.\mathrm{T}_{\text {mean }}\right)$, daily air degree days $\left(\right.$ Air $\left.\mathrm{T}_{\mathrm{DD}}\right)$, air cumulative degree days (Air $\left.\mathrm{T}_{\mathrm{CDD}}\right)$, minimum soil temperature $\left(\right.$ Soil $\left._{\mathrm{T}_{\min }}\right)$, maximum soil temperature $\left(\right.$ Soil $\left.\mathrm{T}_{\max }\right)$, mean soil temperature (Soil $\left.\mathrm{T}_{\text {mean }}\right)$, daily soil degree days (Soil $\left.\mathrm{T}_{\mathrm{DD}}\right)$, soil cumulative degree days $\left(\mathrm{Soil}_{\mathrm{CDD}}\right)$, mean relative humidity $\left(\right.$ Relative humidity $\mathrm{mean}_{\text {m }}$ ), and mean dew point $\left(\right.$ Dew point $\left._{\text {mean }}\right)$. Air and soil degree days (DD) and cumulative degree days (CDD) were calculated using the single-sine method with upper and lower thresholds of 25 and $10^{\circ} \mathrm{C}$, respectively. CDD were calculated beginning on 1 January.

${ }^{c}$ Correct predictions: percentage of days in which the indicated EFI value correctly predicted the occurrence or nonoccurrence of $C$. purpurea ascospores; false positives: percentage of days in which the indicated EFI value incorrectly predicted the occurrence of $C$. purpurea ascospores when none were captured; and false negatives: percentage of days in which the indicated EFI value failed to predict the occurrence of $C$. purpurea ascospores.

d ns: not significant at $P=0.05$. All other $\chi^{2}$ values are significant at $P<0.05$ using the Pearson $\chi^{2}$ test.

Table 4. $\chi^{2}\left(\chi^{2}\right)$ analyses of environmental favorability indices used to predict the occurrence of at least one Claviceps purpurea ascospore in 2013, 2014, 2015, and all three years combined in Umatilla Co., $\mathrm{OR}^{\mathrm{a}}$

\begin{tabular}{|c|c|c|c|c|c|c|c|c|}
\hline \multirow[b]{2}{*}{$\begin{array}{l}\text { Environmental } \\
\text { Favorability Index }(\mathbf{E F I})^{\mathbf{b}}\end{array}$} & \multicolumn{4}{|c|}{2013} & \multicolumn{4}{|c|}{2014} \\
\hline & $\chi^{2}$ & $\begin{array}{c}\text { Correct } \\
\text { predictions }\end{array}$ & $\begin{array}{c}\text { False } \\
\text { positives }^{\mathbf{c}}\end{array}$ & $\begin{array}{c}\text { False } \\
\text { negatives }\end{array}$ & $\chi^{2}$ & $\begin{array}{c}\text { Correct } \\
\text { predictions }\end{array}$ & $\begin{array}{c}\text { False } \\
\text { positives }\end{array}$ & $\begin{array}{c}\text { False } \\
\text { negatives }\end{array}$ \\
\hline $\mathrm{EFI}_{\text {Air }}=0$ & 42.63 & $20.4 \%$ & $21.1 \%$ & $58.6 \%$ & 13.48 & $28.4 \%$ & $13.5 \%$ & $58.2 \%$ \\
\hline $\mathrm{EFI}_{\text {Air }} \geq 1$ & 42.63 & $79.6 \%$ & $12.5 \%$ & $7.9 \%$ & 13.48 & $71.6 \%$ & $19.1 \%$ & $9.2 \%$ \\
\hline $\mathrm{EFI}_{\text {Air }} \geq 2$ & 32.14 & $71.7 \%$ & $5.9 \%$ & $22.4 \%$ & 16.10 & $67.4 \%$ & $9.9 \%$ & $22.7 \%$ \\
\hline $\mathrm{EFI}_{\text {Air }} \geq 3$ & 17.63 & $61.2 \%$ & $4.6 \%$ & $34.2 \%$ & 13.70 & $62.4 \%$ & $7.1 \%$ & $30.5 \%$ \\
\hline $\mathrm{EFI}_{\text {Air }} \geq 4$ & 16.58 & $54.6 \%$ & $1.3 \%$ & $44.1 \%$ & 9.74 & $56.7 \%$ & $5.7 \%$ & $37.6 \%$ \\
\hline $\mathrm{EFI}_{\text {Air }}=5$ & 12.99 & $48.0 \%$ & $0.0 \%$ & $52.0 \%$ & $3.52 \mathrm{~ns}^{\mathrm{d}}$ & $39.7 \%$ & $0.7 \%$ & $59.6 \%$ \\
\hline $\mathrm{EFI}_{\text {Soil }}=0$ & 89.91 & $12.5 \%$ & $33.6 \%$ & $53.9 \%$ & 18.42 & $27.0 \%$ & $16.3 \%$ & $56.7 \%$ \\
\hline $\mathrm{EFI}_{\text {Soil }} \geq 1$ & 89.91 & $87.5 \%$ & $0.0 \%$ & $12.5 \%$ & 18.42 & $73.0 \%$ & $16.3 \%$ & $10.6 \%$ \\
\hline $\mathrm{EFI}_{\text {Soil }} \geq 2$ & 54.33 & $75.0 \%$ & $0.0 \%$ & $25.0 \%$ & 12.46 & $65.2 \%$ & $10.6 \%$ & $24.1 \%$ \\
\hline $\mathrm{EFI}_{\text {Soil }} \geq 3$ & 34.36 & $64.5 \%$ & $0.0 \%$ & $35.5 \%$ & 4.50 & $56.7 \%$ & $10.6 \%$ & $32.6 \%$ \\
\hline $\mathrm{EFI}_{\text {Soil }} \geq 4$ & 23.82 & $57.2 \%$ & $0.0 \%$ & $42.8 \%$ & 19.54 & $61.0 \%$ & $2.8 \%$ & $36.2 \%$ \\
\hline \multirow[t]{2}{*}{$\mathrm{EFI}_{\text {Soil }}=5$} & 5.41 & $40.1 \%$ & $0.0 \%$ & $59.9 \%$ & 13.42 & $51.1 \%$ & $0.7 \%$ & $48.2 \%$ \\
\hline & & & & & & & \multicolumn{2}{|c|}{ (continued on next page) } \\
\hline
\end{tabular}

\footnotetext{
a Weather data were collected from the Oregon AgriMet HRMO weather station, which was located at the HAREC in Umatilla Co., Oregon and approximately 3.0 to $19.4 \mathrm{~km}$ from the field sites.

${ }^{b}$ Weather variables used in the $\mathrm{EFI}_{\text {Air }}$ model included minimum air temperature (Air $\mathrm{T}_{\min }$ ), maximum air temperature (Air $\mathrm{T}_{\max }$ ), mean air temperature (Air $\mathrm{T}_{\text {mean }}$ ), daily air degree days (Air $\mathrm{T}_{\mathrm{DD}}$ ), and air cumulative degree days (Air $\mathrm{T}_{\mathrm{CDD}}$ ). Weather variables used in the $\mathrm{EFI}_{\text {Soil }}$ model included minimum soil temperature (Soil $\mathrm{T}_{\min }$ ), maximum soil temperature $\left(\right.$ Soil $\mathrm{T}_{\max }$ ), mean soil temperature (Soil $\mathrm{T}_{\text {mean }}$ ), daily soil degree days (Soil $\mathrm{T}_{\mathrm{DD}}$ ), and soil cumulative degree days (Soil $\mathrm{T}_{\mathrm{CDD}}$ ). Air and soil degree days (DD) and cumulative degree days (CDD) were calculated using the single-sine method with upper and lower thresholds of 25 and $10^{\circ} \mathrm{C}$, respectively. CDD were calculated beginning on 1 January.

${ }^{c}$ Correct predictions: percentage of days in which the indicated EFI value correctly predicted the occurrence or nonoccurrence of $C$. purpurea ascospores; false positives: percentage of days in which the indicated EFI value incorrectly predicted the occurrence of $C$. purpurea ascospores when none were captured; and false negatives: percentage of days in which the indicated EFI value failed to predict the occurrence of $C$. purpurea ascospores.

d ns: not significant at $P=0.05$. All other $\chi^{2}$ values are significant at $P<0.05$ using the Pearson $\chi^{2}$ test.
} 
predictors of initial ascospore occurrence. In this study, daily degree days were calculated using a base temperature of $10^{\circ} \mathrm{C}$ and upper threshold of $25^{\circ} \mathrm{C}$, and cumulative degree days were calculated beginning on 1 January. It is possible that adjustments to the base temperature or upper threshold may reduce the range of cumulative degree days and improve their predictive ability; however, several studies have observed reduced sclerotia germination at temperatures below $10^{\circ} \mathrm{C}$ and above $25^{\circ} \mathrm{C}$ (Mitchell and Cooke 1968; Uppala et al. 2011; Uppala et al. 2016). Although a period of preconditioning cold treatment is not necessarily required for the germination of $C$. purpurea sclerotia, maximum sclerotial germination occurs after at least 4 weeks of preconditioning between 0 and $10^{\circ} \mathrm{C}$ (Mitchell and Cooke 1968), but germination may be inhibited when sclerotia are exposed to longer durations of

Table 3. (continued from preceding page)

\begin{tabular}{|c|c|c|c|c|c|c|c|}
\hline \multicolumn{4}{|c|}{2015} & \multicolumn{4}{|c|}{ Combined } \\
\hline$\chi^{2}$ & $\begin{array}{c}\text { Correct } \\
\text { predictions }\end{array}$ & $\begin{array}{c}\text { False } \\
\text { positives }\end{array}$ & $\begin{array}{c}\text { False } \\
\text { negatives }\end{array}$ & $\chi^{2}$ & $\begin{array}{c}\text { Correct } \\
\text { predictions }\end{array}$ & $\begin{array}{c}\text { False } \\
\text { positives }\end{array}$ & $\begin{array}{c}\text { False } \\
\text { negatives }\end{array}$ \\
\hline 4.59 & $54.3 \%$ & $6.2 \%$ & $39.5 \%$ & 25.57 & $59.3 \%$ & $10.1 \%$ & $30.5 \%$ \\
\hline 17.81 & $65.4 \%$ & $10.5 \%$ & $24.1 \%$ & 35.16 & $60.4 \%$ & $8.1 \%$ & $31.4 \%$ \\
\hline 26.70 & $67.9 \%$ & $6.2 \%$ & $25.9 \%$ & 49.67 & $62.4 \%$ & $6.4 \%$ & $31.2 \%$ \\
\hline 6.58 & $58.0 \%$ & $10.5 \%$ & $31.5 \%$ & 36.81 & $60.9 \%$ & $8.1 \%$ & $31.0 \%$ \\
\hline 49.00 & $72.8 \%$ & $0.6 \%$ & $26.5 \%$ & 113.18 & $67.9 \%$ & $0.7 \%$ & $31.4 \%$ \\
\hline 29.87 & $66.7 \%$ & $2.5 \%$ & $30.9 \%$ & 79.15 & $65.3 \%$ & $3.3 \%$ & $31.4 \%$ \\
\hline 31.10 & $69.1 \%$ & $4.9 \%$ & $25.9 \%$ & 56.48 & $63.3 \%$ & $5.7 \%$ & $31.0 \%$ \\
\hline 35.41 & $69.1 \%$ & $2.5 \%$ & $28.4 \%$ & 77.57 & $65.5 \%$ & $3.7 \%$ & $30.8 \%$ \\
\hline 30.26 & $67.9 \%$ & $3.7 \%$ & $28.4 \%$ & 66.05 & $64.2 \%$ & $4.6 \%$ & $31.2 \%$ \\
\hline 49.00 & $72.8 \%$ & $0.6 \%$ & $26.5 \%$ & 117.65 & $68.4 \%$ & $0.4 \%$ & $31.2 \%$ \\
\hline $0.21 \mathrm{~ns}^{\mathrm{d}}$ & $50.6 \%$ & $16.1 \%$ & $33.3 \%$ & 8.27 & $55.4 \%$ & $13.8 \%$ & $30.8 \%$ \\
\hline 6.02 & $39.5 \%$ & $16.1 \%$ & $44.4 \%$ & 8.57 & $55.4 \%$ & $13.6 \%$ & $31.0 \%$ \\
\hline
\end{tabular}

Table 4. (continued from preceding page)

\begin{tabular}{|c|c|c|c|c|c|c|c|}
\hline \multicolumn{4}{|c|}{2015} & \multicolumn{4}{|c|}{ Combined } \\
\hline$\chi^{2}$ & $\begin{array}{c}\text { Correct } \\
\text { predictions }\end{array}$ & $\begin{array}{c}\text { False } \\
\text { positives }\end{array}$ & $\begin{array}{c}\text { False } \\
\text { negatives }\end{array}$ & $\chi^{2}$ & $\begin{array}{c}\text { Correct } \\
\text { predictions }\end{array}$ & $\begin{array}{c}\text { False } \\
\text { positives }\end{array}$ & $\begin{array}{c}\text { False } \\
\text { negatives }\end{array}$ \\
\hline 36.69 & $25.9 \%$ & $31.5 \%$ & $42.6 \%$ & 95.50 & $24.8 \%$ & $22.4 \%$ & $52.7 \%$ \\
\hline 36.69 & $74.1 \%$ & $14.2 \%$ & $11.7 \%$ & 95.50 & $75.2 \%$ & $15.2 \%$ & $9.7 \%$ \\
\hline 27.91 & $70.4 \%$ & $11.1 \%$ & $18.5 \%$ & 76.11 & $69.9 \%$ & $9.0 \%$ & $21.1 \%$ \\
\hline 22.33 & $65.4 \%$ & $5.6 \%$ & $29.0 \%$ & 55.49 & $63.1 \%$ & $5.7 \%$ & $31.2 \%$ \\
\hline 13.44 & $58.0 \%$ & $2.5 \%$ & $39.5 \%$ & 41.51 & $56.5 \%$ & $3.1 \%$ & $40.4 \%$ \\
\hline 5.47 & $50.6 \%$ & $0.6 \%$ & $48.8 \%$ & 22.66 & $46.4 \%$ & $0.4 \%$ & $53.2 \%$ \\
\hline 37.78 & $27.2 \%$ & $38.9 \%$ & $34.0 \%$ & 137.88 & $22.2 \%$ & $30.1 \%$ & $47.7 \%$ \\
\hline 37.78 & $72.8 \%$ & $6.8 \%$ & $20.4 \%$ & 137.88 & $77.8 \%$ & $7.5 \%$ & $14.7 \%$ \\
\hline 39.01 & $71.6 \%$ & $3.7 \%$ & $24.7 \%$ & 101.87 & $70.8 \%$ & $4.6 \%$ & $24.6 \%$ \\
\hline 36.76 & $69.1 \%$ & $1.9 \%$ & $29.0 \%$ & 67.59 & $63.7 \%$ & $4.0 \%$ & $32.3 \%$ \\
\hline 32.68 & $66.7 \%$ & $0.0 \%$ & $32.1 \%$ & 75.82 & $61.8 \%$ & $1.3 \%$ & $36.9 \%$ \\
\hline 31.68 & $65.4 \%$ & $0.6 \%$ & $34.0 \%$ & 44.17 & $52.5 \%$ & $0.4 \%$ & $47.0 \%$ \\
\hline
\end{tabular}


Table 5. $\chi^{2}\left(\chi^{2}\right)$ validation of environmental favorability indices used to predict the occurrence of at least one Claviceps purpurea ascospore using historical spore trap data from 2008, 2010, 2012, and all three years combined in Umatilla Co., OR ${ }^{\mathrm{a}}$

\begin{tabular}{|c|c|c|c|c|c|c|c|c|}
\hline \multirow[b]{2}{*}{$\begin{array}{l}\text { Environmental } \\
\text { Favorability Index (EFI) } \\
\end{array}$} & \multicolumn{4}{|c|}{2008} & \multicolumn{4}{|c|}{2010} \\
\hline & $x^{2}$ & $\begin{array}{c}\text { Correct } \\
\text { predictions }\end{array}$ & $\begin{array}{c}\text { False } \\
\text { positives }\end{array}$ & $\begin{array}{c}\text { False } \\
\text { negatives }\end{array}$ & $\chi^{2}$ & $\begin{array}{c}\text { Correct } \\
\text { predictions }\end{array}$ & $\begin{array}{c}\text { False } \\
\text { positives }\end{array}$ & $\begin{array}{c}\text { False } \\
\text { negatives }\end{array}$ \\
\hline $\mathrm{EFI}_{\mathrm{Air}}=0$ & $7.73 \mathrm{~ns}^{\mathrm{d}}$ & $8.8 \%$ & $2.9 \%$ & $88.2 \%$ & 13.77 & $20.8 \%$ & $9.2 \%$ & $70.0 \%$ \\
\hline $\mathrm{EFI}_{\mathrm{Air}} \geq 1$ & $7.73 \mathrm{~ns}$ & $91.2 \%$ & $8.8 \%$ & $0.0 \%$ & 13.77 & $79.2 \%$ & $10.8 \%$ & $10.0 \%$ \\
\hline $\mathrm{EFI}_{\mathrm{Air}} \geq 2$ & $2.99 \mathrm{~ns}$ & $88.2 \%$ & $8.8 \%$ & $2.9 \%$ & 9.97 & $70.0 \%$ & $7.5 \%$ & $22.5 \%$ \\
\hline $\mathrm{EFI}_{\mathrm{Air}} \geq 3$ & $0.43 \mathrm{~ns}$ & $64.7 \%$ & $5.9 \%$ & $29.4 \%$ & 5.63 & $59.2 \%$ & $5.8 \%$ & $35.0 \%$ \\
\hline $\mathrm{EFI}_{\text {Air }} \geq 4$ & $0.02 \mathrm{~ns}$ & $52.9 \%$ & $5.9 \%$ & $41.2 \%$ & 3.89 & $50.0 \%$ & $4.2 \%$ & $45.8 \%$ \\
\hline $\mathrm{EFI}_{\mathrm{Air}}=5$ & $1.63 \mathrm{~ns}$ & $38.2 \%$ & $0.0 \%$ & $61.8 \%$ & 4.62 & $33.3 \%$ & $0.0 \%$ & $66.7 \%$ \\
\hline $\mathrm{EFI}_{\text {Soil }}=0$ & $0.14 \mathrm{~ns}$ & $14.7 \%$ & $0.0 \%$ & $85.3 \%$ & $1.26 \mathrm{~ns}$ & $29.2 \%$ & $5.8 \%$ & $65.0 \%$ \\
\hline $\mathrm{EFI}_{\text {Soil }} \geq 1$ & $0.14 \mathrm{~ns}$ & $85.3 \%$ & $11.8 \%$ & $2.9 \%$ & $1.26 \mathrm{~ns}$ & $70.8 \%$ & $14.2 \%$ & $15.0 \%$ \\
\hline $\mathrm{EFI}_{\text {Soil }} \geq 2$ & $3.27 \mathrm{~ns}$ & $82.4 \%$ & $5.9 \%$ & $11.8 \%$ & $0.56 \mathrm{~ns}$ & $59.2 \%$ & $10.8 \%$ & $30.0 \%$ \\
\hline $\mathrm{EFI}_{\text {Soil }} \geq 3$ & $3.77 \mathrm{~ns}$ & $73.5 \%$ & $2.9 \%$ & $23.5 \%$ & 16.30 & $61.7 \%$ & $1.7 \%$ & $36.7 \%$ \\
\hline $\mathrm{EFI}_{\text {Soil }} \geq 4$ & $1.42 \mathrm{~ns}$ & $58.8 \%$ & $2.9 \%$ & $38.2 \%$ & 8.63 & $46.7 \%$ & $0.8 \%$ & $52.5 \%$ \\
\hline \multirow[t]{2}{*}{$\mathrm{EFI}_{\text {Soil }}=5$} & $1.39 \mathrm{~ns}$ & $35.3 \%$ & $0.0 \%$ & $64.7 \%$ & $1.58 \mathrm{~ns}$ & $25.0 \%$ & $0.0 \%$ & $75.0 \%$ \\
\hline & & & & & & & \multicolumn{2}{|c|}{ (continued on next page } \\
\hline
\end{tabular}

\footnotetext{
a Weather data were collected from the Oregon AgriMet HRMO weather station located at the HAREC in Umatilla Co., OR.

b Weather variables used in the $\mathrm{EFI}_{\text {Air }}$ model included minimum air temperature (Air $\mathrm{T}_{\min }$ ), maximum air temperature (Air $\left.\mathrm{T}_{\max }\right)$, mean air temperature $($ Air $\mathrm{T}_{\text {mean }}$ ), daily air degree days (Air $\mathrm{T}_{\mathrm{DD}}$ ), and air cumulative degree days (Air $\mathrm{T}_{\mathrm{CDD}}$ ). Weather variables used in the EFI $\mathrm{E}_{\text {soil }}$ model included minimum soil

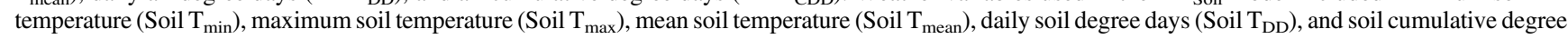
days $\left(\right.$ Soil $\mathrm{T}_{\mathrm{CDD}}$ ). Air and soil degree days (DD) and cumulative degree days (CDD) were calculated using the single-sine method with upper and lower thresholds of 25 and $10^{\circ} \mathrm{C}$, respectively. CDD were calculated beginning on 1 January.

c Correct predictions: percentage of days in which the indicated EFI value correctly predicted the occurrence or nonoccurrence of $C$. purpurea ascospores; false positives: percentage of days in which the indicated EFI value incorrectly predicted the occurrence of $C$. purpurea ascospores when none were captured; and false negatives: percentage of days in which the indicated EFI value failed to predict the occurrence of $C$. purpurea ascospores.

d ns: not significant at $P=0.05$. All other $\chi^{2}$ values are significant at $P<0.05$ using the Pearson $\chi^{2}$ test.
}

temperatures between 0 and $5^{\circ} \mathrm{C}$ (Mitchell 1972; Uppala et al. 2011; Uppala et al. 2016). Adjusting the starting date of degree day accumulation may improve the predictive ability of cumulative degree days since $C$. purpurea sclerotia are deposited in fields during harvest in July and exposed to field conditions for at least 8 months before they begin to germinate and release ascospores in April or May the following year. The wide range of cumulative degree days observed at the first occurrence of ascospores may also reflect the fact that large numbers of sclerotia can be deposited and overwinter at different depths in the soil (Alderman et al. 1993; Dung et al. 2016), exposing them to varying temperatures and temperature fluctuations during the winter and spring. In addition, sclerotia can vary greatly in size which can affect the number and size of stromata that arise from a given sclerotium (Cooke and Mitchell 1966) as well as the timing and duration of sclerotia germination (Cooke and Mitchell 1966; Mitchell and Cooke 1968).

The time period of ascospore production observed in the Columbia Basin of eastern Oregon was slightly different than that observed by Cooke and Mitchell in Great Britain, where it was documented that sclerotia began to germinate in early June and the germination period only persisted for 3 weeks (Cooke and Mitchell 1967). Between 2013 and 2015, thousands of ascospores (16,237 to 114,525 total per season) were observed in all commercial field sites and most ascospores were observed between mid May and mid June, corresponding to the typical flowering period for many perennial ryegrass cultivars in the area. Correspondingly, ergot incidence and severity were high in all of the fields and plots that were used in this study (data not shown). The large numbers of ascospores observed, especially in older fields, were not surprising considering that thousands of sclerotia can be collected from fields after harvest (Alderman et al. 1993; Dung et al. 2016) and each sclerotium can potentially produce hundreds or thousands of ascospores (Alderman 2006; Alderman et al. 2015). Such large concentrations of ascospores represent significant sources of primary inoculum that can be extremely difficult to control, especially considering that the Burkard spore traps were calibrated to sample only 10 liters of air per min. Additionally, sclerotia of $C$. purpurea can form multiple capitula over several weeks, extending the period of potential infection and reducing the likelihood of disease escape by otherwise susceptible grasses (Cooke and Mitchell 1966, 1967; Mitchell and Cooke 1968). Using cultivars with short and uniform flowering periods can limit the exposure of unfertilized flowers to ascospores and reduce ergot incidence and severity (Kaur et al. 2015b), and more research is needed to help develop cultivars that escape or resist $C$. purpurea infection.

Although cumulative air degree days were not useful in determining the first occurrence of ascospores, $94 \%$ of the total ascospores trapped during 2013, 2014, and 2015 were captured when cumulative air degree days were between 230.1 and 403.7. This range of cumulative degree days corresponded to a 21 to 27 day period beginning in early to mid May and ending in early to mid June. This information may be useful in timing protective fungicide applications during a period when initial inoculum pressure is likely to be the greatest.

To our knowledge, this is the first study to develop predictive models for the occurrence of $C$. purpurea ascospores. Further research is needed to develop and/or validate predictive models for other cool season grass seed production regions in Oregon. Nevertheless, the ability to identify days when $C$. purpurea ascospores are likely to be present will enable growers to make more informed decisions about when, or even if, fungicide applications are needed during anthesis. Although these models are not intended to be used alone, they could be an important component of an integrated disease management strategy that incorporates cultural practices (Chastain et al. 1997; Kaur et al. 2015b), field scouting (Dung et al. 2016), spore trapping (Alderman et al. 2015; Dung et al. 2015), chemical control (Dung et al. 2012; Kaur et al. 2015a), and grower outreach (Walenta et al. 2015) to improve ergot management in perennial ryegrass seed crops.

\section{Acknowledgments}

Funding for this research was provide by the Columbia Basin Grass Seed Association, the Oregon Seed Council, the Union County Seed Growers Association the Washington State Commission on Pesticide Registration, and the Washington Turfgrass Seed Commission. We would like to thank Riverview Seed in Hermiston, OR, for providing study sites and in-kind support. The authors would like to acknowledge Javier Almaguer, Tim Weinke, and Phil Rogers for providing technica assistance. Thank you to the two anonymous reviewers for providing helpful suggestions that greatly improved this manuscript. 
Table 5. (continued from preceding page)

\begin{tabular}{|c|c|c|c|c|c|c|c|}
\hline \multicolumn{4}{|c|}{2012} & \multicolumn{4}{|c|}{ Combined } \\
\hline$\chi^{2}$ & $\begin{array}{c}\text { Correct } \\
\text { predictions }\end{array}$ & $\begin{array}{c}\text { False } \\
\text { positives }\end{array}$ & $\begin{array}{c}\text { False } \\
\text { negatives }\end{array}$ & $\chi^{2}$ & $\begin{array}{c}\text { Correct } \\
\text { predictions }\end{array}$ & $\begin{array}{c}\text { False } \\
\text { positives }\end{array}$ & $\begin{array}{c}\text { False } \\
\text { negatives }\end{array}$ \\
\hline $0.02 \mathrm{~ns}$ & $25.4 \%$ & $1.7 \%$ & $72.9 \%$ & 14.62 & $20.2 \%$ & $6.1 \%$ & $73.7 \%$ \\
\hline $0.02 \mathrm{~ns}$ & $74.6 \%$ & $16.9 \%$ & $8.5 \%$ & 14.62 & $79.8 \%$ & $12.2 \%$ & $8.0 \%$ \\
\hline $0.38 \mathrm{~ns}$ & $66.1 \%$ & $11.9 \%$ & $22.0 \%$ & 11.98 & $71.8 \%$ & $8.9 \%$ & $19.2 \%$ \\
\hline $0.01 \mathrm{~ns}$ & $45.8 \%$ & $8.5 \%$ & $45.8 \%$ & 4.46 & $56.3 \%$ & $6.6 \%$ & $37.1 \%$ \\
\hline $0.26 \mathrm{~ns}$ & $42.4 \%$ & $5.1 \%$ & $52.5 \%$ & $3.80 \mathrm{~ns}$ & $48.4 \%$ & $4.7 \%$ & $46.9 \%$ \\
\hline $1.82 \mathrm{~ns}$ & $30.5 \%$ & $0.0 \%$ & $69.5 \%$ & 8.44 & $33.3 \%$ & $0.0 \%$ & $66.7 \%$ \\
\hline 4.32 & $23.7 \%$ & $8.5 \%$ & $67.8 \%$ & 4.95 & $25.4 \%$ & $5.6 \%$ & $69.0 \%$ \\
\hline 4.32 & $76.3 \%$ & $10.2 \%$ & $13.6 \%$ & 4.95 & $74.6 \%$ & $12.7 \%$ & $12.7 \%$ \\
\hline $2.95 \mathrm{~ns}$ & $64.4 \%$ & $6.8 \%$ & $28.8 \%$ & 4.74 & $64.3 \%$ & $8.9 \%$ & $26.8 \%$ \\
\hline $0.67 \mathrm{~ns}$ & $52.5 \%$ & $6.8 \%$ & $40.7 \%$ & 18.77 & $61.0 \%$ & $3.3 \%$ & $35.7 \%$ \\
\hline $1.22 \mathrm{~ns}$ & $44.1 \%$ & $3.4 \%$ & $52.5 \%$ & 11.44 & $47.9 \%$ & $1.9 \%$ & $50.2 \%$ \\
\hline $2.43 \mathrm{~ns}$ & $33.9 \%$ & $0.0 \%$ & $66.1 \%$ & 5.78 & $29.1 \%$ & $0.0 \%$ & $70.9 \%$ \\
\hline
\end{tabular}

\section{Literature Cited}

Alderman, S. C. 1991. Assessment of ergot and blind seed diseases of grasses in the Willamette Valley of Oregon. Plant Dis. 75:1038-1041.

Alderman, S. C. 1993. Aerobiology of Claviceps purpurea in Kentucky bluegrass. Plant Dis. 77:1045-1049.

Alderman, S. C. 2006. Ergot: Biology and Control. USDA-ARS, Corvallis, OR. Available at: http://www.ars.usda.gov/sp2userfiles/person/81/ergotdvdtranscript. pdf. Accessed on: 12/31/2014.

Alderman, S. C., Churchill, D. B., and Bilsland, D. M. 1993. A vacuum collection and seed separation technique for enumeration of sclerotia of Claviceps purpurea in perennial ryegrass fields. Plant Dis. 77:1020-1022.

Alderman, S. C., Coats, D. D., and Crowe, F. J. 1996. Impact of ergot on Kentucky bluegrass grown for seed in northeastern Oregon. Plant Dis. 80:853-855.

Alderman, S. C., Coats, D. D., Crowe, F. J., and Butler, M. D. 1998. Occurrence and distribution of ergot and estimates of seed loss in Kentucky bluegrass grown for seed in central Oregon. Plant Dis. 82:89-93.

Alderman, S. C., Halse, R. R., and White, J. F. 2004. A reevaluation of the host range and geographical distribution of Claviceps species in the United States. Plant Dis. 88:63-81.

Alderman, S. C., Walenta, D. L., and Hamm, P. B. 2010. Timing of occurrence of Claviceps purpurea ascospores in northeast Oregon. Plant Health Prog. doi: 10.1094/PHP-2010-1123-01-RS

Alderman, S. C., Walenta, D. L., Hamm, P. B., Martin, R. C., Dung, J., and Kosman, E. 2015. Afternoon ascospore release in Claviceps purpurea optimizes perennial ryegrass infection. Plant Dis. 99:1410-1415.

Anonymous. 2014. Oregon Agriculture: Facts and Figures July 2014. Salem, OR: Oregon Department of Agriculture. Oregon Department of Agriculture, Salem, OR.

Burch, M., and Levetin, E. 2002. Effects of meteorological conditions on spore plumes. Int. J. Biometeorol. 46:107-117.

Butler, M. D., Alderman, S. C., Hammond, P. C., and Berry, R. E. 2001. Association of insects and ergot (Claviceps purpurea) in Kentucky bluegrass seed production fields. J. Econ. Entomol. 94:1471-1476.

Chastain, T. G., Kiemnec, G. L., Cook, G. H., Garbacik, C. J., Quebbeman, B. M., and Crowe, F. J. 1997. Residue management strategies for Kentucky bluegrass seed production. Crop Sci. 37:1836-1840.

Cleveland, W. S., Devlin, S. J., and Grosse, E. 1988. Regression by local fitting: Methods, properties, and computational algorithms. J. Econom. 37:87-114.

Cooke, R. C., and Mitchell, D. T. 1966. Sclerotium size and germination in Claviceps purpurea. Trans. Br. Mycol. Soc. 49:95-100.

Cooke, R. C., and Mitchell, D. T. 1967. Germination pattern and capacity for repeated stroma formation in Claviceps purpurea. Trans. Br. Mycol. Soc. 50:275-283.

Craig, A. M., Klotz, J. L., and Duringer, J. M. 2015. Cases of ergotism in livestock and associated ergot alkaloid concentrations in feed. Front Chem. 3:8.

Cunfer, B., Mathre, D. E., and Hockett, E. A. 1975. Factors influencing the susceptibility of male-sterile barley to ergot. Crop Sci. 15:194-196.

Dung, J. K. S., Alderman, S. C., Walenta, D. L., and Hamm, P. B. 2014. Environmental factors influencing airborne ascospore concentrations of ergot in perennial ryegrass and exploratory development of a predictive model. Phytopathology 104:S3.181.

Dung, J. K. S., Alderman, S. C., Walenta, D. L., and Hamm, P. B. 2016. Spatial patterns of ergot and quantification of sclerotia in perennial ryegrass seed fields in eastern Oregon. Plant Dis. 100:1110-1117.

Dung, J. K. S., Scott, J. C., Alderman, S. C., Kaur, N., Walenta, D. L., Frost, K. E., and Hamm, P. B. 2015. Development of a DNA-based protocol to detect airborne ergot spores in cool-season grass seed fields. Pages 31-34 in: 2015 Seed Production Research at Oregon State University USDA-ARS Cooperating, USDA-ARS Cooperating. Ext/CrS 152. N. Anderson, A. Hulting, D. Walenta, M. Flowers, and C. Sullivan, eds. Oregon State Univ., Corvallis.

Dung, J. K. S., Walenta, D. L., Alderman, S. C., and Hamm, P. B. 2012. Spatial patterns of Claviceps purpurea in Kentucky bluegrass and perennial ryegrass grown for seed and effect of soil-applied fungicides on germination of ergot sclerotia. Pages 21-27 in: 2012 Seed Production Research at Oregon State University, USDA-ARS Cooperating. Ext/CrS 143. A. Hulting, N. Anderson, D. Walenta, and M. Flowers, eds. Oregon State Univ., Corvallis.

Fidanza, M. A., Dernoeden, P. H., and Grybauskas, A. P. 1996. Development and field validation of a brown patch warning model for perennial ryegrass turf Phytopathology 86:385-390.

Granke, L. L., and Hausbeck, M. K. 2010. Influence of environment on airborne spore concentrations and severity of asparagus purple spot. Plant Dis. 94 843-850.

Kaminski, J. E., Dernoeden, P. H., and Fidanza, M. A. 2007. Environmental monitoring and exploratory development of a predictive model for dead spot of creeping bentgrass. Plant Dis. 91:565-573.

Kaur, N., Alderman, S. C., Walenta, D. L., Frost, K. E., Dung, J. K. S., and Hamm, P. B. 2015a. Evaluation of new fungicide chemistries and application strategies to reduce ergot in grass seed production systems. Pages 31-34 in: 2015 Seed Production Research at Oregon State University USDA-ARS Cooperating, USDA-ARS Cooperating. Ext/CrS 152. N. Anderson, A. Hulting, D. Walenta, M. Flowers, and C. Sullivan, eds. Oregon State Univ., Corvallis.

Kaur, N., Dung, J. K. S., Alderman, S. C., Walenta, D. L., Frost, K. E., and Hamm, P. B. 2015b. Evaluation of perennial ryegrass cultivars for klendusity to ergot. Phytopathology 105:S4.70.

Krause, R. A., and Massie, L. B. 1975. Predictive systems: Modern approaches to disease control. Annu. Rev. Phytopathol. 13:31-47.

Luttrell, E. S. 1980. Host-parasite relationships and development of the ergot sclerotium in Claviceps purpurea. Can. J. Bot. 58:942-958.

Markhasseva, M. V. A. 1936. A method for the prognosis of the development of ergot (Claviceps purpurea Tul.). Summ. Sci. Res. Wk Inst. Pl. Prot. Leningr 1935:535-537.

Mitchell, D. T. 1972. The effects of temperature on germination and ethanol soluble carbohydrate physiology of sclerotia of Claviceps purpurea (Fr.) Tul. from the south-western cape. J. S. Afr. Bot. 38:45-53.

Mitchell, D. T., and Cooke, R. C. 1968. Some effects of temperature on germination and longevity of sclerotia in Claviceps purpurea. Trans. Br. Mycol. Soc. 51:721-729.

Nutter, F. W., Cole, H., Jr., and Schein, R. D. 1983. Disease forecasting system for warm weather Pythium blight of turfgrass. Plant Dis. 67:1126-1128.

Pscheidt, J. W., and Ocamb, C. M. eds. 2016. Pacific Northwest Plant Disease Management Handbook. Oregon State University, Corvallis, OR. http:// pnwhandbooks.org/plantdisease.

Shelby, R. A. 1999. Toxicology of ergot alkaloids in agriculture. Pages 469-477 in: Ergot: The Genus Claviceps. Křen, V., and Cvak, L., eds. Harwood Academic Publishers, The Netherlands.

Troutt, C., and Levetin, E. 2001. Correlation of spring spore concentrations and meteorological conditions in Tulsa, Oklahoma. Int. J. Biometeorol. 45:64-74.

Tudzynski, P., and Scheffer, J. 2004. Claviceps purpurea: Molecular aspects of a unique pathogenic lifestyle. Mol. Plant Pathol. 5:377-388.

Uppala, S., Wu, B., Alderman, S., and Gilmore, L. 2011. Studies on the epidemiology of ergot in Kentucky bluegrass. Pages 13-22 in: Oregon State University Central Oregon Agricultural Research Center 2011 Annual Report. Central Oregon Agricultural Research Center, Madras, OR.

Uppala, S., Wu, B., and Alderman, S. C. 2012. Effects of preconditioning cold treatments and incubation temperature on germination of ergot bodies of Claviceps purpurea from Kentucky bluegrass. Phytopathology 102:S4.123.

Uppala, S. S., Wu, B. M., and Alderman, S. C. 2016. Effects of temperature and duration of preconditioning cold treatment on sclerotial germination of Claviceps purpurea. Plant Dis. 100:2080-2086.

USDA-NASS. 2012. NASS Quick Stats.. Available at https://quickstats.nass.usda gov/. Accessed on 9/3/2016. USDA-NASS, Washington, DC. 
Walenta, D. L., Hamm, P. B., and Alderman, S. C. 2008. Monitoring of ergot (Claviceps purpurea) ascospore release to better time fungicide application in NE Oregon grass seed production. Pages 34-38 in: Seed Production Research. Ext/CrS 128, 3/09.W. C. Young III, ed. Oregon State University, Corvallis.

Walenta, D. L., Kaur, N., Alderman, S. C., Frost, K. E., Hamm, P. B., and Dung, J. K. S. 2015. Using information technology to advance integrated ergot disease management in perennial grass seed cropping systems. Pages 35-38 in: Seed Production Research. Ext/CrS 152, 4/16. N. Anderson, A. Hulting, D. Walenta, M. Flowers, and C. Sullivan, eds. Oregon State University, Corvallis.

Zalom, F. G., Goodell, P. B., Wilson, L. T., Barnett, W. W., and Bentley, W. J. 1983 Degree-days: The calculation and use of heat units in pest management. UC-DANR Leaflet 21373. University of California, Davis. 